\title{
KEPEMIMPINAN UNGGUL KEPALA SEKOLAH DASAR DAERAH TERPENCIL (Studi Multisitus pada Sekolah Dasar di Kabupaten Bondowoso)
}

\author{
Juharyanto \\ Jurusan Administrasi Pendidikan Universitas Negeri Malang \\ Jl. Semarang 565145 \\ Email: juharyanto.fip@um.ac.id
}

\begin{abstract}
This study aims at describing the problem and capacity of leadership, the role of excellent leadership, and its behaviors of Elementary School's Principal in remote areas. This research used the qualitative approach with multi-sites study design. The data were collected through in-depth interviews, participant observation, documentation and it analyzed inductively using modified analytic. The results showed that; 1) Elementary schools in remote areas have similar relative leadership problems and capacity; 2) there is four dominant excellent leadership played by the principal in realizing an effective school, among others: spiritual leadership, transformational leadership, the leadership of learning, and leadership of enterprener.
\end{abstract}

Keywords: superior leadership, elementary school, remote area

\begin{abstract}
Abstrak: Penelitian ini bertujuan untuk mendeskripsikan problem dan daya dukung kepemimpinan, peran kepemimpinan unggul, dan perilaku kepemimpinan unggul Kepala SD daerah terpencil. Penelitian ini menggunakan pendekata kualitatif dengan rancangan studi multisitus. Data dikumpulkan melalui wawancara mendalam; observasi berperan serta; studi dokumentasi dan dianalisis secara induktif analitik yang dimodifikasi. Hasil penelitian menunjukkan; 1) SD di daerah terpencil memiliki problem dan dukungan kepemimpinan yang relatif sama; 2) terdapat empat kepemimpinan unggul dominan yang diperankan kepala sekolah dalam mewujudkan sekolah efektif, antara lain: kepemimpinan spiritual, kepemimpinan transformasional, kepemimpinan pembelajaran, dan kepemimpinan enterprener.
\end{abstract}

Kata kunci:, kepemimpinan unggul, sekolah dasar, terpencil

Kebijakan otonomi daerah telah melahirkan sistem desentralisasi. Desentralisasi diharapkan membuat perubahan yang mendasar terhadap berbagai sektor pemerintahan, termasuk sektor pendidikan (Saud, 2012). Desentralisasi, khususnya di bidang pendidikan diintroduksi sebagai jawaban atas kegagalan sistem sentralisasi dalam melakukan pemberdayaan kepada masyarakat pendidikan sesuai dengan potensi konteksnya masing-masing (Jeong et al., 2017a; Dworkin, 2001). Desentralisasi merupakan solusi terbaik bagi berdayanya sekolah dalam ber- peran serta meningkatkan mutu anak-anak bangsa ke depan.

Setidaknya terdapat tiga hal ideal dari penerapan sistem desentralisasi, antara lain: 1) kepastian kekuatan lembaga terpilih; 2) keterlibatan pemangku kepentingan; dan 3) proses pengambilan keputusan (Gessler \& Ashmawy, 2014). Senada dengan Gessler, Nugroho (2014) menyatakan bahwa desentralisasi bidang pendidikan memang diharapkan setidaknya membawa 4 dampak positif terutama berkaitan dengan: 1) peningkatan mutu, 2) efisiensi 
keuangan, 3) efisiensi administrasi, dan 4) perluasan dan pemerataan pada daerah pelosok sehingga terjadi perluasan dan pemerataan pendidikan secara nasional. Garis besar utama dari kedua pendapat tersebut adalah, desentralisasi memberikan peluang yang besar bagi sekolah untuk berdaya secara mandiri. Dengan demikian, tidak akan ada lagi sekolah yang akan mengalami ketertinggalan baik secara kuantitatif maupun kualitatif. Perubahan dari sistem sentralistis menuju desentralistis dengan memberikan kewenangan yang luas kepada sekolah dalam mengelola sekolah, mengarah pada penerapan pola manajemen berbasis sekolah (MBS). Sekolah pada akhirnya dikehendaki menjadi organisasi yang dimiliki bersama oleh seluruh komponen sekolah. Kepemilikan bersama tersebut menjadi driven bagi seluruh sumber daya manusia sekolah untuk memikirkan, mengusahakan, dan memajukan sekolah hingga benar-benar unggul, sebagaimana dicitakan.

Meskipun desentralisasi pendidikan meru-pakan suatu konsekuensi kebijakan otonomi daerah yang secara ideal menguntungkan sekolah, namun realitas perjalanan dalam dua dasa warsa ini, desentralisasi pendidikan terkesan dipaksakan dan belum bisa diterima secara proporsional oleh keseluruhan satuan pendidikan, khususnya mereka yang berlokasi di daerah-daerah pinggiran (remote area). Disamping itu, menurut INFID, sejak pemberlakuan desentralisasi di Indonesia, dua pertiga nasib dan kualitas hidup warga, dalam praktiknya, sangat ditentukan oleh baik-buruknya kinerja pemerintah daerah, mulai dari soal kebersihan lingkungan, seperti pengelolaan sampah, hingga kualitas sekolah dan pelayanan kesehatan. Dengan demikian pemerintah memiliki kontribusi yang signifikan terhadap kualitas sekolah atau pendidikan dan pengajaran, walaupun sedang berada dalam sistem desentralisasi.

Dalam konteks kesadaran tersebut, berbagai upaya telah ditempuh oleh pemerintah baik pusat maupun daerah melalui stakeholders terkait dalam upaya meningkatkan kualitas sekolah. Program pembangunan unit sekolah baru, rehabilitasi sekolah, penambahan ruang kelas baru, sertifikasi, non job training dan in service training, penyediaan program pembinaan yang teratur, penyiapan forum akademik, di samping kegiatan supervisi dan masih banyak lagi kegiatan lainnya (Mulyasa, 2012), namun program-program tersebut belum benar- benar menyentuh sekolah secara keseluruhan, khususnya di sekolah terpencil.

Pak Pondong, Kepala SD Negeri 1 Gunosari dan merangkap sebagai kepala SDN 1 Tlogosari 4 serta Kepala SMP Negeri Satu Atap 1 Tlogosari, menjelaskan bahwa:

Sekolah kami, khususnya di sini (Pen: SDN Gunosari 1) hanya memiliki 3 orang guru PNS dari 12 guru seluruhnya, sudah termasuk SD dan SMP SATAP-nya. Jumlah murid kami banyak, lebih 195 orang dengan 6 rombel SD dan 3 rombel SMP. Kami sungguh membutuhkan guru PNS. Ya... Bapak kan tahu sendiri, bagaimana saya bisa mengajak mereka lari hanya dengan honor sangat kecil sekitar 200 ribu per bulan, itu pun kami juga ketakutan karena mereka tidak ber SK guru honorer, yang secara aturan tidak bisa dihonor. Bupati belum mengeluarkan SK honorer karena belum ada aturannya, katanya. Belum lagi sarananya. Bapak pirso sendiri, meja dan kursinya sudah kurang layak kan? Kami sudah mengajukan ke Diknas, sudah cukup lama itu. Namun belum ada berita. Kami ingin berkualitas, tapi masih seperti ini kenyataannya. Namun kualitas tetap kami kejar bersama-sama guru.

Pak Hartono, Kepala SD Negeri Kaligedang Sempol juga menjelaskan bahwa:

Kalau bicara kualitas, siapa yang tidak ingin Pak? Semua guru terus berusaha keras juga. Namun sarpras kami hanya seperti ini keadaannya. Bantuan susah kami terima. Padahal semua pejabat sudah tahu keadaan sebenarnya. Mungkin karena di pinggiran ya? Sehingga yang di kota yang didahulukan. Tapi kita kapan? Gurunya juga kurang. Partisipasi masyarakatnya juga seperti ini. Pokoknya banyak persoalannya. Tapi sebagai kepala sekolah harus pinter-pinter menyiasati dan berusaha. Pokoknya demi anak-anak, apapun akan kami lakukan yang terbaik.

Duadeskripsikepalasekolahdiatas, menyiratkan tiga hal pokok, antara lain: 1) keterbatasan sumber daya; 2) tingginya keinginan kepala sekolah untuk memberi akses layanan pendidikan dan pengajaran seluas-luasnya; 3) kuatnya ide dan antusiasme kepala sekolah untuk mengejar mutu sekolah. Tiga hal tersebut, merupakan hal biasa bagi para kepala sekolah di perkotaan atau berlokasi dekat pusat pemerintahan kabupaten hingga desa/kelurahan, tetapi sangat istimewa jika dimiliki oleh kepala sekolah pinggiran, dengan keterbatasan yang amat 
sangat. Dalam konteks tersebut, kepala sekolah memiliki keinginan keras dan integritas tak terbendung untuk menembus status quo, terutama dalam peningkatan mutu pendidikan di sekolah dasar yang bergantung kepada kepala sekolah, sebagai pimpinan tertinggi di sekolah. Motivasi dan integritas tak terbendung tersebut merupakan modal utama dalam menginspirasi dan menggerakkan seluruh sumber daya manusia lainnya untuk bergerak bersama menggapai asa pendidikan dan pengajaran yang berkualitas serta dinikmati oleh seluruh masyarakat sekolah sesuai dengan konteks budaya yang melingkupinya.

Bapak Slamet Hari Wahyudi, guru Sukwan SDN Gunusari 1 Tlogosari menyatakan:

Saya dan teman-teman saya yang sukwan, walau bayarannya tidak seberapa merasa nyaman di sini. Sebagai guru bahasa Inggris, sebenarnya ijazah saya bukan itu, tapi eksakta. Namun karena gurunya sangat kurang, bagaimana lagi... ditambah dengan pembinaan-pembinaan tentang peningkatan kompetensi, penanaman semangat mengajar dengan ikhlas semata-mata untuk anak-anak di desa sini... apalagi kepala sekolah juga memberi contoh kedisiplinan, kerajinan, dan selalu mengusahakan tambahan bayaran, ya... kami menyadari dan harus berusaha keras untuk memajukan sekolah ini juga. Anu..., apa ya... pokoknya demi anak-anak di sini lah. Kasihan kalau tidak ada yang memperdulikannya. Kami semua di sini berkomitmen untuk berjuang. Makanya di sini pembiasaan keagamaan terus diadakan, supaya kami tetap teguh berjuang.

Sementara itu, Bapak Agus Agus Margianto, guru SD Negeri Kaligedang Sempol, yang merangkap sebagai guru SMP Negeri Satu Atap Sempol menjelaskan bahwa:

Semua warga sekolah di sini selalu saling memberi semangat. Semangat itu yang kami miliki dan pupuk terus-menerus. Saya sebenarnya kasihan dengan teman-teman guru sukwan. Gajinya sangat minim. Padahal tugasnya sama dengan saya. Tapi pak Hartono (kepala sekolah) selalu punya banyak cara untuk menjadi teladan bagi kami. Semangat juang beliau selalu dicontoh teman-teman. Akhirnya ya... semua jadi seperti itu juga. Di sini secara rutin diadakan rapat pembinaan, diawali dengan doa bersama, ngaji, dan lain-lain. Penanaman nilai perjuangan dan kesungguhan dalam mengajar selalu dipentingkan. Kita tahu anak-anak desa kan seperti itu. Tapi kami tidak menyerah, pasti ada jalan untuk menjadi terbaik. Ini yang terus dibangun. Tapi sesuai dengan kemampuan kami dan keadaan yang di masyarakat sini.

Deskripsi tersebut menyiratkan kedekatan emosionalyang demikian dalam antar warga sekolah. Basisnya adalah nilai-nilai yang berkembang dalam konteks budaya setempat.

Berkaitan dengan hal tersebut, beberapa riset kepemimpinan dalam konteks dan budaya yang berbeda pada beberapa dasawarsa menyimpulkan bahwa nilai-nilai kejujuran, integritas, keberpihakan pada kebenaran, dan keterlibatan mendalam secara emosional dan personal pada seluruh personel organisasi dipandang sebagai penentu utama bagi keberhasilan praktik kepemimpinan suatu organisasi (Bezzina, 2000; Brown \& Posner, 2001; Swanson, 2010). Kerinduan atas sajian autentik tentang nilainilai integritas dan kebenaran yang menghargai variasi konteks dan budaya oleh keseluruhan sumber daya organisasi adalah fakta dan harus diperjuangkan dan ditampakkan (Bhindi \& Duignan, 1997; Juharyanto, 2012). Otentifikasi nilai-nilai tersebut memicu timbulnya kobaran motivasi spiritual organisasional dan secara signifikan berdampak pada lahirnya keberdayaan SDM (Sumber Daya Manusia) organisasi yang menguatkan capaian tujuan organisasi secara bersama dan sempurna (Fry, 2003).

Lebih lanjut Fry (2003) menyatakan bahwa pada galibnya, kepemimpinan bersumber pada intelektualitas, hati, pikiran, dan jiwa individu-individu pemimpin yang menyebar secara berkelanjutan pada SDM organisasi lainnya melalui interaksi yang bermakna. Kebermaknaan interaksi tersebut merupakan "penggerak yang kokoh" bagi terwujudnya kesadaran kepemimpinan bagi SDM organisasi dalam berkontribusi secara total menuju capaian tujuan kepemimpinan efektif dalam berbagai situasi dan kondisi apapun.

Dari beberapa riset tentang kepemimpinan pendidikan di sekolah, ditemukan bahwa "nafsu" berprestasi (efektivitas sekolah) hanya diperoleh melalui kuatnya kesadaran kepemimpinan yang merangsek kuat ke dalam diri individu seluruh stakeholders pendidikan yang disemangati oleh keteladanan berprestasi kepala sekolah dalam bentuk jalinan interaksi bermakna melalui pemanfaatan nilai-nilai kepemimpinan berdasar penyesuaian dengan variasi konteks budaya secara konsisten (Juharyanto, 2012). Pemimpin tidak sekedar sadar bahwa mereka ada bersamanya, 
tetapi lebih jauh dan dalam bahwa mereka adalah SDM dinamis yang memiliki cita-cita indah di masa depan dan membutuhkan tempat dan kesempatan untuk berkembang secara maksimal demi tujuan organisasi sebagai komunitas belajar mereka (Fullan \& Fullan, 2007; Mitchell \& Sackney, 2016; Juharyanto, 2012, 2014). Karenanya, kepemimpinan efektif hanya akan terjadi jika etika dan nilai-nilai kepemimpinan menjadi dasar utama pemimpin dalam melaksanakan kepemimpinannya (Brown, J. \& Townsend, 1997).

Dengan demikian, definisi praktik kepemimpinan efektif sangat bergantung pada beberapa hal, diantaranya ragam budaya, bentuk dan konteks organisasi, keunikan dinamis individu organisasi, dan isu-isu yang sedang dihadapi, dialami dan akan terjadi. Konsep kepemimpinan akhirnya harus dimaknai dalam konteks yang lebih luas, lebih bermakna, dan lebih relevan dengan kehidupan nyata masyarakat beserta kecenderungannya, khususnya dalam konteks masyarakat terpencil, yang sangat jarang tersentuh oleh riset-riset di bidang pendidikan, padahal konteks keterpencilan tersebut riil dan merupakan kendala nyata yang perlu diatasi Howley (dalam Juharyanto, 2012).

Penelitian ini bertujuan untuk: 1) mendes-kripsikan peran-peran kepemimpinan Unggul Kepala SD daerah terpencil Kabupaten Bondowoso provinsi Jawa Timur, dan 2) mendeskripsikan perilaku kepemimpinan Unggul Kepala SD daerah terpencil Kabupaten Bondowoso provinsi Jawa Timur. Hasil penelitian ini diharapkan akan memperoleh informasi atau data tentang kepemimpinan unggul kepala SD daerah terpencil, di samping pula dapat menjadi sajian data awal/rujukan bagi peneliti berikutnya dalam mengembangkan sebuah penelitian pengembangan kepemimpinan unggul kepala SD daerah terpencil dalam mewujudkan sekolah efektif sesuai dengan autentisitas konteks masyarakat sekolah dasar tersebut.

\section{METODE}

Penelitian ini dilaksanakan dengan tiga tujuan, yaitu untuk mendeskripsikan problem dan daya dukung SD daerah terpencil, mendeskripsikan peran-peran kepemimpinan dan perilaku kepemimpinan unggul kepala SD daerah terpencil dalam mewujudkan sekolah efektif sesuai dengan autentisitas konteks masyarakat sekolah. Agar apa yang diteliti tersebut betul-betul terungkap diperlukan pengamatan yang dalam, maka menurut Bogdan \& Biklen (1998), Marshall \& Rossmann (2006), Maxwell $(1996,2013)$ sebaiknya proses tersebut didekati secara kualitatif. Karena itu, di dalam penelitian ini digunakan pendekatan kualitatif. Di bidang pendidikan penelitian dengan pendekatan kualitatif itu sering kali disebut penelitian naturalistik (Lincoln \& Guba, 1985). Dengan pendekatan tersebut, obyek kajian diamati dalam keutuhannya dan sebagaimana terjadinya secara ilmiah (natural) di dalam latarnya (Marshall \& Rossmann, 2006).

Penelitian ini dirancang dengan menggunakan rancangan studi multisitus. Sebagaimana dikemu-kakan oleh Bogdan \& Biklen (1998), rancangan studi multisitus tersebut merupakan satu bentuk rancangan penelitian kualitatif yang memang dapat digunakan terutama untuk pengembangan teori yang diangkat dari beberapa latar penelitian yang memiliki kesamaan karakteristik, sehingga bisa menghasilkan teori dengan generalisasi yang lebih luas dan lebih umum penerapannya. Ada tiga teknik yang digunakan dalam mengumpulkan data penelitian ini, yaitu: (1) wawancara mendalam; (2) observasi berperan serta; serta (3) studi dokumentasi. Ketiga teknik tersebut memang merupakan teknik-teknik dasar yang selalu digunakan oleh peneliti kualitatif di dalam penelitian-penelitiannya (Marshall \& Rossmann, 2006; Creswell, 2010, 2012).

Ada dua analisis data yang dilakukan dalam penelitian. Pertama, analisis data di lapangan, yaitu analisis data pada setiap selesai satu kali pengumpulan data, dalam bentuk penyusunan refleksi pengumpulan pada akhir pembuatan catatan lapangan. Menurut Bogdan \& Biklen (1998) setiap akhir catatan lapangan peneliti harus menulis refleksi yang berisi temuan sementara penelitian, informan/situasi sosial/dokumen yang akan dikejar berikut dan rencana pengumpulan data berikut. Selanjutnya temuan-temuan penelitian pada akhir setiap pengumpulan data dianalisis lebih lanjut pada setiap akhir bulan pengumpulan data. Kedua, analisis data dilakukan setelah seluruh pengumpulan data selesai atau setelah kembali dari lapangan. Ada dua tahap analisis data setelah selesai seluruh pengumpulan data. Pertama, analisis data situs tunggal yang dipaparkan berdasarkan jenis kepemimpinan kepala sekolah dalam mewujudkan sekolah efektif. Langkah-langkah analisis situs tunggal dalam penelitian ini mengikuti saran Bogdan \& Biklen (1998), yang meliputi: (1) penyusunan 
seluruh cacatan lapangan berdasarkan kronologis waktu pengumpulan data; (2) reduksi data dengan menggunakan teknik potong dan tempel; (3) pemaparan dan analisis domain data; (4) penarikan kesimpulan. Pemaparan data didasarkan jenis peran kepemimpinan yang ditemukan melalui penelitian ini. Kedua, analisis data lintas situs melalui analisis komparatif konstan. Dalam hal ini temuan-temuan sementara analisis data SD Negeri Gunusari 1 Tlogosari dibandingkan dengan temuan-temuan sementara analisis data SDN Kaligedang Sempol Bondowoso. Melalui teknik analisis komparatif konstan dihasilkan temuan-temuan akhir penelitian.

\section{HASIL}

Melalui analisis situs tunggal dan analisis lintas situs dengan menggunakan teknik analisis komparatif konstan, diperoleh temuan-temuan penelitian. Pertama, sebagai sekolah dasar dengan latar guru/ staf, sarana-prasarana, infrastruktur, lokasi, dan masyarakat yang tidak jauh berbeda, kedua sekolah tersebut menghadapi permasalahan sekaligus daya dukung yang relatif sama. Masalah-masalah tersebut antara lain: guru PNS sangat kurang, kualifikasi guru belum sesuai standar, kompetensi masih perlu perbaikan, tidak semua guru berijazah linear, dukungan masyarakat rendah, lokasi terpencil, infrastruktur tidak memadai, tingkat pendidikan mayoritas wali murid rendah, tingkat ekonomi masyarakat dan wali murid rendah, kesadaran pendidikan rendah, sekolah harus melaksanakan program sekolah inklusi, sarana dan prasarana belum memadai, BOS sebagai satu-satunya sumber pendanaan. Sedangkan daya dukungnya antara lain: semangat kerja tinggi, mengajar fokus pada pengabdian, interaksi antar guru harmonis, interaksi guru dengan masyarakat menyenangkan, dukungan tokoh masyarakat kuat, gairah belajar siswa cenderung baik, fanatisme keagamaan masyarakat tinggi, lahan pertanian dan perkebunan subur, dukungan kebijakan pemerintah baik, sekolah tersebut merupakan sekolah binaan UNESCO. Ked$u a$, terdapat empat model kepemimpinan dominan yang diperankan kepala sekolah dalam mewujudkan sekolah efektif, antara lain: kepemimpinan spiritual, kepemimpinan transformasional, kepemimpinan pembelajaran, dan kepemimpinan enterprener. Ketiga, sebagai pemimpin spiritual ada empat perilaku kepemimpinan kepala sekolah dalam mewujudkan sekolah efektif, meliputi: (1) kerja keras yang didasari tanggung jawab dan ikhlas melayani,
(2) kedisiplinan; (3) kejujuran; (4) keteladanan; dan (5) selalu bersyukur dalam setiap meraih keberhasilan dan kegagalan yang didasari dengan keikhlasan dan kesabaran. Keempat, sebagai pemimpin transformasional dalam mewujudkan sekolah efektif, terdapat 3 perilaku kepemimpinan kepala sekolah, antara lain: (1) distribusi visi dan misi; (2) integrasi nilai-nilai kepemimpinan; (3) menguatkan budaya organisasi sekolah. Kelima, pemimpin pembelajaran, ada enam perilaku kepemimpinan kepala sekolah dalam mewujudkan sekolah efektif, yaitu (1) memahami dan menyamakan visi, tujuan, harapan dalam mewujudkan sekolah efektif; (2) memahami dan menyamakan visi tentang karakteristik pembelajaran sesuai dengan konteks sekolah; (3) mengembangkan budaya baru pembelajaran sesuai dengan konteks sekolah; (4) mengembangkan segala perangkat pembelajaran yang dibutuhkan dalam mengembangkan budaya baru dalam pembelajaran sesuai dengan tuntutan konteks sekolah; (5) mendorong peran komite sekolah sangat baik dalam mewujudkan sekolah efektif; dan (6) evaluasi rutin untuk menjamin keberhasilan dalam mewujudkan sekolah efektif. Keenam, sebagai pemimpin enterprener, ada sembilan perilaku kepemimpinan kepala dalam mewujudkan sekolah efektif, yaitu (1) Budaya independensi yang kuat; (2) pemahaman visi yang jelas; (3) positif terhadap potensi kegagalan; (4) budaya belajar sepanjang hayat; (5) kekuatan imajinasi (6) berbasis nilai multidimensional; (7) pemberdayaan; (8) kolegialitas; dan (9) nilai juang.

Temuan tersebut dengan lebih jelas dapat dilihat pada gambar 1 .

Dalam proses pelaksanaan kepemimpinan guna mendukung terwujudnya sekolah efektif, kepemimpinan dominan yang paling utama adalah kepemimpinan spiritual. Nilai-nilai kepemimpinan spiritual diintegrasikan ke dalam kepemimpinan instruksional dan kepemimpinan enterprener melalui kepemimpinan transformasional dalam beragam bentuk program dan kegiatan yang disepakati oleh seluruh sumber daya sekolah. Empat kepemimpinan dominan dan interaksi antar keempatnya dapat dilihat pada gambar 2 .

\section{PEMBAHASAN}

\section{Kepala Sekolah sebagai Pemimpin Spiritual}

Kepemimpinan spiritual merupakan penggabungan nilai, sikap, dan perilaku yang diperlukan 
untuk memotivasi diri dan orang lain secara intrinsik, sehingga terpacu untuk melakukan banyak hal bagi kebaikan organisasi secara maksimal. Kepemimpinan spiritual meliputi tugas: 1) menciptakan suatu visi yang setiap anggota dalam organisasi memiliki rasa terpanggil untuk memberi makna dan perbedaan dalam kehidupannya; 2) Membangun budaya sosial dan atau organisasi berdasarkan cinta altruistis (lawan dari sifat a-sosial atau egois), sehingga antara pemimpin dan yang dipimpin memiliki rasa saling memperhatikan, peduli, menghargai den- gan tulus, antar anggota merasa dipahami dan dihargai. Peran sebagai pemimpin spiritual dicerminkan dan diaktualisasikan dalam tindakan dan perbuatan. Kepala sekolah yang baik harus bisa menjadi contoh dan teladan bagi seluruh warga sekolah. Proses kepemimpinan yang demikian itu akan memberikan energi dan motivasi tinggi, komitmen, rasa percaya diri kepada tim. Selain itu, kepemimpinan berbasis nilai juga dapat memberikan kontribusi positif pada visi, misi, dan pemimpin (Phipps, 2012). Maharana, et. al (2014) menyatakan bahwa untuk sebuah or-

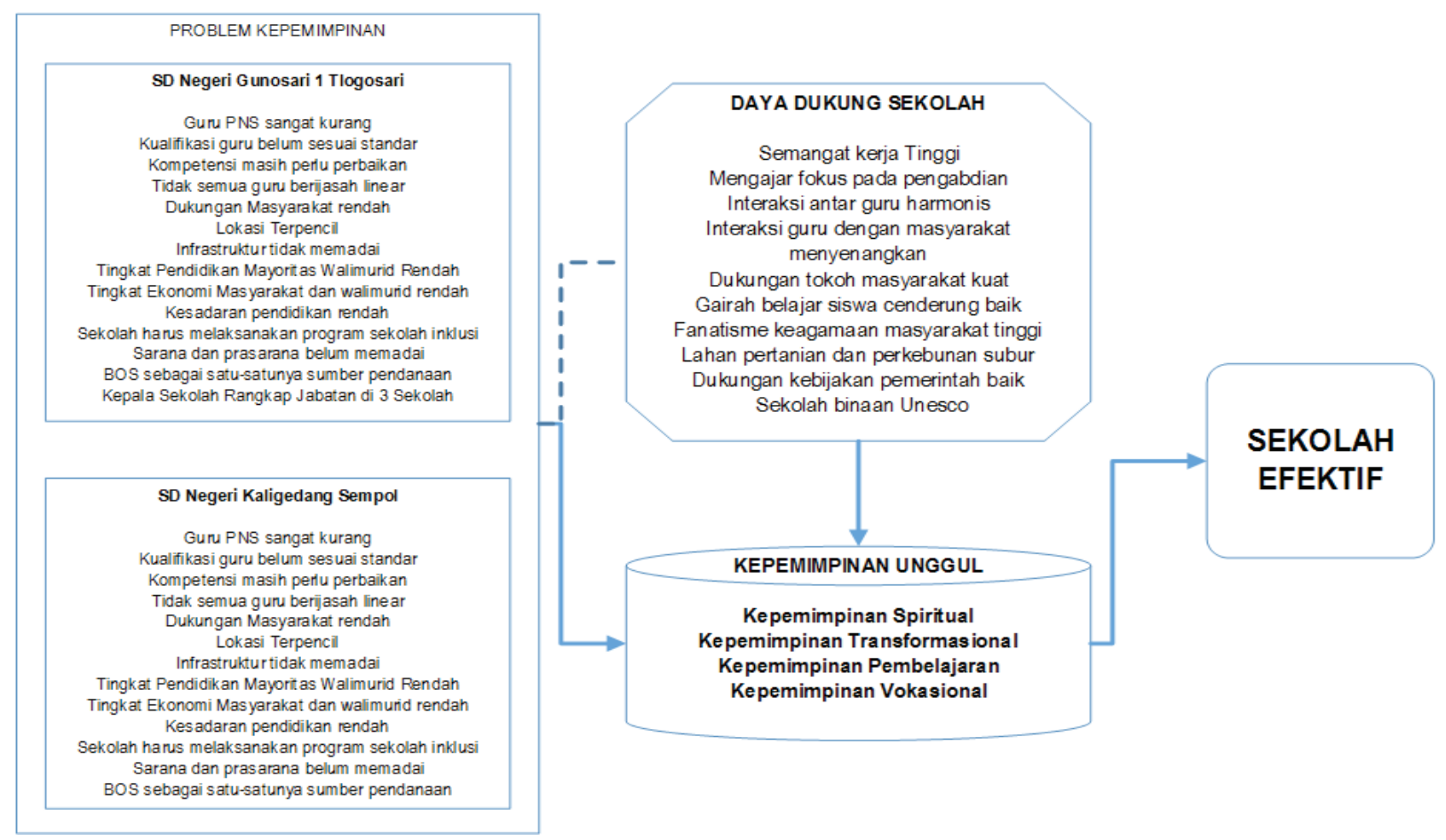

Gambar 1. Paparan Hasil Temuan Umum

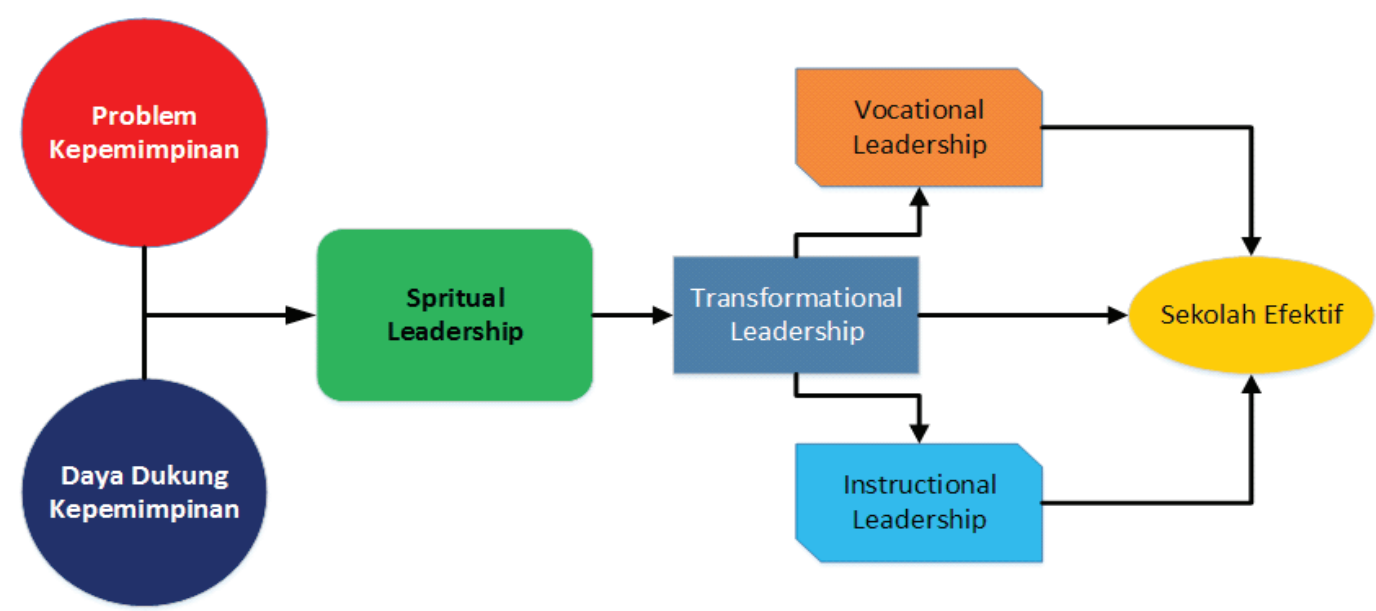

Gambar 2. Hubungan antar Kepemimpinan Dominan Kepala Sekolah 
ganisasi yang ingin berkinerja tinggi harus mempunyai keselarasan yang kuat antara nilai-nilai pribadi karyawan, organisasi, dan nilai-nilai yang diinginkan karyawan.

Nilai spiritual yang lain dan bisa dilakukan kepala sekolah yaitu kejujuran, kedisiplinan, dan tanggung jawab. Sikap tersebut dilakukan oleh kepala sekolah dalam menjalankan perannya sebagai pemimpin spiritual. Ada empat karakteristik pemimpin spiritual dilakukan oleh kepala sekolah, yaitu 1) kejujuran; 2) kedisiplinan; 3) tanggung jawab; dan 4) keteladanan. Dari penjelasan tersebut dapat disimpulkan bahwa kepemimpinan spiritual dapat diartikan sebagai kepemimpinan keteladanan. Kepala sekolah merupakan orang pertama dan pertama yang meyakini seluruh nilai kebaikan dan diterapkannya. Menerapkan nilai kebaikan dalam bentuk perilaku sehari-hari, merupakan bagian penting dari sosialisasi tentang nilai kebaikan itu sendiri. Keberhasilan praktik kepemimpinan spiritual, menjadi modal utama kepala sekolah dalam integrasi nilai ke dalam seluruh sumber daya. Kepala sekolah demikian merupakan daya tarik tersendiri bagi seluruh sumber daya lain untuk menerapkannya dengan sebaik-baiknya, yang secara nyata berdampak pada dukungan terwujudnya sekolah efektif.

Hal ini sejalan dengan hukum ketertarikan (law of attraction) yaitu bahwa setiap individu memiliki getaran positif dan negatif, bilamana seseorang memancarkan getaran positifnya (dalam berpikir, beremosi, bertindak positif) ia akan mendapat respons balik yang positif pula dan bahkan berlipat ganda, demikian pula sebaliknya (Rasmussen, 2010). Karakteristik penting dari pemimpin masa depan senantiasa berusaha menjadi model/teladan dan mengkomunikasikan keteladanannya melalui kedalaman keyakinan dan ide-ide serta perilaku kesehariannya, atau menurut Boyatzis \& McKee (2010) disebut dengan istilah resonant leader.

\section{Kepala Sekolah sebagai Pemimpin Transformasional}

Kepemimpinan dilaksanakan ketika seseorang memobilisasi sumber daya institusional, politis, psikologis dan sumber lain untuk membangkitkan, melibatkan dan memotivasi pengikutnya (Paredes, 2002). Terdapat 3 perilaku kepemimpinan kepala sekolah, antara lain: (1) distribusi visi dan misi; (2) integrasi nilai-nilai kepemimpinan; (3) menguatkan budaya organisasi sekolah

Pemimpin transformasional adalah seseorang pemimpin yang menguasai situasi dengan menyampaikan visi yang jelas tentang tujuan kelompok, bergairah dalam pekerjaan dan kemampuan untuk membuat anggota kelompok merasa diisi ulang dan berenergi (Cherry, 2017).

Kepemimpinan transformasional adalah jenis gaya kepemimpinan yang mengarah ke perubahan positif pada mereka yang mengikuti (pengikut). Pemimpin transformasional umumnya meletakkan keyakinan terhadap nilai energisitas, antusiasme dan spirit tinggi dalam setiap denyut organisasi sekolah agar efektif. Tidak hanya para pemimpin memperhatikan dan terlibat dalam proses, mereka juga fokus untuk membantu setiap anggota kelompok untuk dapat berhasil juga (Bertocci, 2009).

Pemimpin transformasional selalu mengikatkan dirinya dengan nilai-nilai yang berlaku dalam bentuk perilaku keseharian, dan meyakini atas terjadinya polarisasi perilaku tersebut ke seluruh warga sekolahnya. Polarisasi nilai-nilai tersebut pada akhirnya akan melahirkan budaya sekolah yang kuat, di mana seluruh warga sekolah memiliki kesadaran penuh bahwa nilai-nilai kebaikan tersebut memberi manfaat tinggi dan mampu melahirkan sekolah efektif. Akhirnya, kepemimpinan transformasional dapat meningkatkan sumber daya manusia secara efektif yang terbangun dari kepercayaan, kekaguman, kesetiaan, dan hormat terhadap pemimpin, yang tiada henti berusaha untuk memotivasi pengikut untuk melakukan sesuatu yang lebih dan melakukannya melampaui harapan mereka sendiri (Ezzedeen, 2005).

\section{Kepala Sekolah sebagai Pemimpin Pembelajaran}

Sebagaimana telah ditegaskan bahwa peran paling penting bagi kepala sekolah adalah pemimpin pembelajaran. Kepemimpinan pembelajaran dapat dilaksanakan dengan baik oleh kepala sekolah yang memiliki kemampuan dan kemauan untuk melaksanakannya. Kepemimpinan pembelajaran adalah tindakan yang dilakukan dengan maksud mengembangkan lingkungan kerja yang produktif dan memuaskan bagi guru, serta pada akhirnya mampu menciptakan kondisi belajar siswa 
meningkat (Eggen, \& Kauchak, 2004). Terdapat tiga model kepemimpinan pembelajaran yang dapat diterapkan dalam rangka meningkatkan capaian sekolah secara efektif, antara lain: kejelasan visi dan misi, fokus pada pembelajaran, dan meningkatkan iklim kerja yang kondusif (Hopkins, 2000).

Karena kepemimpinan pembelajaran berkontribusi sangat signifikan terhadap peningkatan prestasi belajar siswa, maka keberadaannya sangat penting untuk diterapkan di sekolah. Kepemimpinan pembelajaran mampu memberikan dorongan dan arahan terhadap warga sekolah untuk meningkatkan prestasi belajar siswanya. Kepemimpinan pembelajaran juga mampu memfokuskan kegiatankegiatan warganya untuk menuju pencapaian visi, misi, dan tujuan sekolah. Kepemimpinan pembelajaran penting diterapkan di sekolah karena kemampuannya dalam membangun komunitas belajar warganya dan bahkan mampu menjadikan sekolahnya sebagai sekolah belajar (learning school) atau sebagai masyarakat yang terus belajar (learning society/community). Kepemimpinan pembelajaran akhirnya menjadi pintu masuk paling efektif dalam meningkatkan prestasi belajar siswa, terutama jika didukung oleh spirit yang membara dalam meraihnya (kepemimpinan spiritual).

Pemahaman tersebut akan memberikan andil yang sangat besar terhadap distribusi konsep tentang sekolah efektif dengan benar kepada warga sekolah. Upaya tiada henti dalam mendistribusi pemahaman tersebut dan mengaplikasinya dari diri pribadi kepala sekolah, merupakan indikasi yang sangat kuat tentang keseriusan kepala sekolah untuk membawa sekolahnya ke arah yang berkualitas. Disamping itu, kepala sekolah sekaligus menjadi model terbaik bagi para warga sekolah dalam menegakkan distributed commitment bidang pembelajaran. Komitmen yang terbangun akan berdampak secara signifikan terhadap peningkatan efektivitas sekolah.

\section{Kepala Sekolah sebagai Pemimpin Enterprener}

Terdapat sembilan perilaku kepemimpinan enterprener kepala dalam mewujudkan sekolah efektif, yaitu (1) Budaya independensi yang kuat; (2) pemahaman visi yang jelas; (3) yakin atas keberhasilan; (4) budaya belajar sepanjang hayat; (5) kekuatan imajinasi (6) berbasis nilai multidimensional; (7) pemberdayaan; (8) kolegialitas; dan (9) nilai juang.
Independensi identik dengan desentralisasi. Independensi sebagai wujud desentralisasi lebih mengarah pada otonomi pendidikan dalam menggali ide, gagasan, inovasi, kreasi, dan kritik konstruktif bahkan finansial berasaskan transparansi, akuntabilitas, kolektif kolegial dengan mengedepankan pemberdayaan partisipasi masyarakat dan stakeholders satuan pendidikan tetapi tetap tidak membentur regulasiregulasi lainnya (Jeong et al., 2017b; Helga, 2014). Desentralisasi berdampak pada meningkatnya tuntutan pada sekolah untuk semakin berdaya dan lebih mengedepankan transparansi (Jeong et al., 2017a).

Pemahaman terhadap visi dan misi merupakan kunci keberhasilan sekolah (Dent, et. al, 2005; Lumby \& Heystek, 2012; Pan, et. al (2015). Visi hendaknya didorong untuk menjadi perwujudan pikiran dan mimpi-mimpi bersama, tidak saja pimpinan, melainkan juga seluruh stafnya (Murphy, 2009). Pimpinan bertugas untuk mendorong keberanian semua bawahan untuk termotivasi meraih visi bersama. Upaya tersebut akan mendudukkan pimpinan sebagai orang yang berhasil menguatkan visi ke seluruh staf (Dennis \& Bocarnea, 2005) sekaligus mendorong kemandirian seluruh staf dalam meraih visi organisasi secara mandiri (Bennis, 2002).

Keyakinan didefinisikan sebagai karakter suatu organisasi, yang keberadaannya menjadi perekat bagi setiap institusi untuk berkembang dan maju bersama meraih visi dalam satu ikatan harmoni normatif regulatif. Ruh keyakinan tersebut meliputi nilai-nilai dasar, tujuan inti, dan memvisikan masa depan. Nilai-nilai ini sangat esensial bagi institusi dalam mengidentifikasi dan mendefinisikan nilainilai utama bagi mereka, termasuk menjadi dasar bagi mereka untuk mengambil peran secara fungsional bagi organisasinya (Wang et al., 2013). Nilainilai dasar tersebut (kejujuran, kepercayaan, integritas, kerja keras, upaya perbaikan diri tanpa henti, pemberdayaan dan kreativitas, kualitas layanan, dan kekuatan pola pikir, sikap dan tindakan holistik) mengakar pada nilai-nilai lokal yang diakui kebenarannya secara massal (perenial). Nilai-nilai tersebut tidak harus berubah karena perubahan yang terjadi di luar, tetapi justru menjadi acuan terbaik bagi terjadinya perubahan di sistem organisasinya (Romero, 2015).

Prinsip belajar sepanjang hayat harus ditegakkan dan dipraktikkan oleh pemimpin (Wilson \& Xue, 2013). Pemimpin perlu mempromosikan lingkungan di mana belajar aktif dapat terjadi. Belajar perlu 
dilihat sebagai kegiatan sosial (Downs, 1995) di mana setiap orang memiliki peran untuk bermain dalam membantu orang untuk belajar. Belajar tidak lagi menjadi kewajiban, melainkan kebutuhan untuk berkembang. Budaya belajar memberikan dampak yang signifikan bagi seluruh staf dalam mencapai tujuan-tujuan organisasi (Mallon, 2010; Shepard, 2000; Silins et al., 2002).

Pemimpin visioner selalu membuat "lompatan mental" dengan mengubah "kondisi tidak mungkin saat ini "menjadi" harus terjadi di masa mendatang". Mereka selalu terikat dengan imajinasi demikian yang dengan komitmen dan kreativitas tinggi, melahirkan energi baru dan cara baru yang mendukung kehidupan organisasi (Meta, 2010). Pemimpin masa depan harus menjadi agen perubahan dan transformasional (Gesell, 2014).

Pemimpin enterprener menjadi seorang pencipta sistem nilai multidimensional yang digemakan ke seluruh sudut organisasi menurut prinsip-prinsip tertentu yang diakui keandalannya atau Covey (2009) menyebutnya dengan istilah a value system centered round principles. Pemimpin akan berhasil jika berupaya melekatkan perilaku manajemen dan kepemimpinannya dengan prinsip-prinsip integritas pribadi, kredibilitas dan hubungan saling percaya (Brown \& Posner, 2001), dan komitmen terhadap nilai-nilai etika dan moral seperti kasih sayang, kerendahan hati dan pelayanan (Juharyanto, 2014) sehingga struktur organisasi, proses dan praktik akan dibangun, dipelihara, dipertahankan dan dikembangkan.

Bawahan kadang mengagumi para pemimpin yang mendelegasikan otoritas mereka, yang membuat bawahan merasa kuat dan mampu (Silins et al., 2002). Ini berarti bahwa para pemimpin telah melakukan pemberdayaan terhadap bawahannya secara tidak langsung. Bawahan menyerahkan kembali kepercayaan, dukungan dan pujian kepada pemimpin, dan ini membantu untuk memperkuat pemimpin dan visi organisasi. Weis (dalam Juharyanto, 2012) menyebutnya dengan istilah "kepemimpinan senyap". "The leader's strongly held values and ability to create a vision toward which others could work (Piter, 2014).

Kepemimpinan tidak bisa menjadi hak prerogatif dari satu orang. Pemimpin masa depan perlu dilatih untuk menguasai seni membentuk tim, berkolaborasi melalui tim daripada mengarahkan dan memberi perintah (Singh et al., 2007; Singh,
2005). Kepemimpinan kolegial mendorong ketahanan organisasi secara berkepanjangan. Menurut Bezzina (2000), setidaknya terdapat 4 alasan perlunya keterlibatan staf dalam organisasi, antara lain: 1) hak prerogatif pimpinan tidak lebih penting daripada keterlibatan semua anggota, 2) setiap orang pada dasarnya ingin dilibatkan dalam setiap usaha menghadapi setiap tantangan perubahan, 3) transformasi nilai-nilai manajerial dan kepemimpinan kepada semua anggota akan menguatkan kemampuan untuk menghadapi tantangan perubahan organisasi, dan 4) kepemilikan bersama.

\section{SIMPULAN DAN SARAN}

\section{Simpulan}

Pertama, masalah-masalah kepemimpinan yang timbul antara lain: guru PNS sangat kurang, kualifikasi guru belum sesuai standar, kompetensi masih perlu perbaikan, tidak semua guru berijazah linear, dukungan masyarakat rendah, lokasi terpencil, infrastruktur tidak memadai, tingkat pendidikan mayoritas wali murid rendah, tingkat ekonomi masyarakat dan wali murid rendah, kesadaran pendidikan rendah, sekolah harus melaksanakan program sekolah inklusi, sarana dan prasarana belum memadai, BOS sebagai satu-satunya sumber pendanaan. Kedua, daya dukung kepemimpinan yang tersedia antara lain: semangat kerja tinggi, mengajar fokus pada pengabdian, interaksi antar guru harmonis, interaksi guru dengan masyarakat menyenangkan, dukungan tokoh masyarakat kuat, gairah belajar siswa cenderung baik, fanatisme keagamaan masyarakat tinggi, lahan pertanian dan perkebunan subur, dukungan kebijakan pemerintah baik, sekolah tersebut merupakan sekolah binaan UNESCO.

Ketiga, terdapat empat kepemimpinan dominan yang diperankan kepala sekolah dalam mewujudkan sekolah efektif, antara lain: kepemimpinan spiritual, kepemimpinan transformasional, kepemimpinan pembelajaran, dan kepemimpinan enterprener.

\section{Saran}

Pola kerja kepemimpinan dapat dilakukan secara kolaborasi dengan bawahan. Kepemimpinan secara kolegial dapat memperkuat kelanjutan suatu organisasi atau lembaga. Untuk meningkatkan kinerja bawahan, diberi kesempatan untuk mengembangkan diri. 


\section{DAFTAR RUJUKAN}

Bennis, W. 2002. Become a tomorrow leader. Focus on Leadership; Servant Leadership for the 21st Century. New York: John Wiley \& Sons, 101109.

Bertocci, D.I. 2009. Leadership in Organizations: There is a Difference Between Leaders and Managers. United States of America: University Press of America, ${ }^{\circledR}$ Inc.

Bezzina, C. 2000. Educational Leadership for Twenty-First Century Malta: Breaking The Bonds of Dependency. International Journal of Educational Management, 299-307.

Bhindi \& Duignan 1997. Leadership for a New Century, Authenticity, Intentionality, Spirituality and Sensibility. Educational Management \& Administration, 25(2): 117.

Bogdan, R. \& Biklen, S.K. 1998. Qualitative research for education: an introduction to theory and methods. Allyn and Bacon.

Boyatzis, R. \& McKee, A. 2010. Resonan leadership, Memperbaharui Diri Anda dan Berhubungan dengan Orang Lain melalui Kesadaran, Harapan dan Kepedulian. Jakarta: PT. Gelora Aksara Pratama.

Brown, J. and Townsend, R. 1997. Developing an ethical framework, Thrust for Educational Leadership. 27(3): 12-14.

Brown, L.M. \& Posner, B.Z. 2001. Exploring The Relationship Between Learning and Leadership. Leadership \& Organization Development Journal, 22(6): 274-280.

Cherry, B.K. 2017. Transformational Leadership Linked to Positive Effects on Study Suggests Transformational Leadership Linked to WellBeing Real-World Applications. 2016-2017.

Covey, S. 2009. Leadership great leaders, great teams, great results.

Creswell, J.W. 2010. Designing and Conducting Mixed Methods Research. 3rd ed. California: Sage Publication.

Creswell, J.W. 2012. Research design: Qualitative, Quantitative, and mixed methods approaches. Journal of investigative surgery: the official journal of the Academy of Surgical Research.

Dent, E.B., Higgins, M.E. \& Wharff, D.M. 2005. Spirituality and Leadership: An Empirical Review of Definitions, Distinctions, and Embedded Assumptions. Leadership Quarterly, 16(5):625-653.
Dworkin, A.G. 2001. Perspectives on Teacher Burnout and School Reform. International Education Journal, 2(2): 69-78.

Eggen, P. and Kauchak, D. 2004. Educational Psychology: Windows, Classrooms. Upper Saddle River: Pearson Prentice Hall.

Ezzedeen, S.R. 2005. Leadership and Power: Identity Processes in Groups and Organizations. Personnel Psychology, London. Thousan Oaks. New Delhi: Sage Publication.

Fry, L.W. 2003. Toward a theory of spiritual leadership. Leadership Quarterly, 14(6): 693727.

Fullan, M. \& Michael Fullan 2007. The New Meaning of Educational Change. New York: Teachers College Press.

Gesell, I. 2014. Facilitative leadership. The Journal for Quality \& Participation, (April): 15-34.

Gessler, M. \& Ashmawy, I.K. 2014. The Effect of Political Decentralization on School Leadership in German Vocational Schools. Education Management Administration \& Leadership, 44(2): 1-21.

Hopkins, D. 2000. Instructional Leadership and School Improvement. Leadership, 1-7.

Jeong, D.W., Lee, H.J. \& Cho, S.K. 2017a. Education Decentralization, School Resources, and Student Outcomes in Korea. International Journal of Educational Development, 53: 1227.

Juharyanto 2012. Implementasi Kompetensi Kepala Sekolah Sebagai Agen Perubahan pada Sekolah Berprestasi: Studi Multi Kasus Pada Tiga Sd/ Mi Berprestasi Di Kabupaten Bondowoso, Kabupaten Jember dan Kabupaten Situbondo. (disertasi) Universitas Negeri Malang.

Juharyanto 2014. Internalisasi Nilai Karakter Dalam Membangun Kultur Organisasi Pendidikan Studi Kasus pada Sekolah Tinggi Agama Islam Bondowoso. Jurnal Pendidikan Lentera Dinas Pendidikan Kabupaten Bondowoso, 1(1):24-35

Lincoln, Y.S. \& Guba, E.G. 1985. Naturalistic inquiry. Beverly Hills: Sage Publications.

Lumby, J. \& Heystek, J. 2012. Leadership Identity in Ethnically Diverse Schools in South Africa and England. Educational Management Administration \& Leadership, 40(1): 4-20.

Maharana, P., Patra, S., Srinivasan, T.M. \& Nagendra, H.R. 2014. A twenty years literature 
on evaluation of spiritual leadership : The new insight for the corporate world. 5(3): 286-292.

Mallon, D. 2010. High-Impact Learning Culture 2010 Executive Summary The Bersin \& Associates. (June).

Marshall, C. \& Rossmann, G.B. 2006. Designing Qualitative Research. Newbury Park, California: SAGE Publication, Inc.

Maxwell, J.A. 1996. Qualitative Reaserch Design: An Interactive Approach. 2nd ed. Thousand Oaks, CA: Sage.

Maxwell, J.A. 2013. Qualitative Research Design. Qualitative Research Design, Thousand Oaks, CA: Sage Publication.

Meta, N., Leadership, L. \& Longoria, E. 2010. Leadership and Management. Leadership, 6190.

Mitchell, C. \& Sackney, L. 2016. School Improvement in High-Capacity Schools : Educational Leadership and Living-Systems Ontology. 44(5): 853-868.

Murphy, N.S. 2009. Nurse Leaders As Stewards: the Beginning of Change. Open Nurs J, 3: 39-44.

Nugroho, P.J. 2014. Faktor-faktor Yang Mempengaruhi Profesionalisme Guru SD Daerah Terpencil Kabupaten Gunung Mas Provinsi Kalimantan Tengah. Jurnal Pendidikan Lentera Dinas Pendidikan Kabupaten Bondowoso, 1(1): 19-36.

Pan, H.-L.W., Nyeu, F.-Y. \& Chen, J.S. 2015. Principal Instructional Leadership in Taiwan: Lessons From Two Decades of Research. Journal of Educational Administration, 53(4, SI): 492-511.

Phipps, K.A. 2012. Spirituality and Strategic Leadership: The Influence of Spiritual Beliefs on Strategic Decision Making. Journal of Business Ethics, 106(2): 177-189.

Rasmussen, S.\& D.H. 2010. Law of Attraction: Uang, Cinta, dan Kebahagiaan. Yogyakarta: Rumpun.
Romero, L.S. 2015. Trust, behavior, and high school outcomes. Journal of Educational Administration, 53(2): 215-236.

Shepard, L.A. 2000. The Role of Assessment in a Learning Culture. 29(7): 4-14.

Silins, H.C., Mulford, W.R. \& Zarins, S. 2002. Organizational Learning and School Change. Educational Administration Quarterly, 38(5): 613-642.

Singh, P. 2005. Use of the Collegial Leadership Model of Emancipation to transform traditional management practices in secondary schools. South African Journal of Education, 25(1): $11-18$.

Singh, P., Manser, P. \& Mestry, R. 2007. Importance of emotional intelligence in conceptualizing collegial leadership in education. South African Journal of Education, 27(3): 541-563.

Swanson, E. 2010. Spiritual Leadership. CRU Press--Green.

Sylvia Downs 1995. Learning at work: effective strategies for making things happen. London: Kogan Page.

Udin Syaefudin Saud 2012. Pengembangan Profesi Guru SD/MI. Bandung: Alfabeta.

Wang, L.H., Gurr, D. \& Drysdale, L. 2013. Successful School Leadership: Case Studies of Four Singapore Primary Schools. Journal of Educational Administration, 54(3): 270-287.

Wilson, M. \& Xue, X. 2013. School Leader Perspectives on Leadership Learning Preparation and Continuing Professional Development in the Chinese Province of Fujian: An Exploratory Study. Educational Management Administration \& Leadership, 41(6): 800-818. 
